\title{
Scour due to Rock Sills in Straight and Curved Horizontal Channels
}

\author{
Stefano Pagliara ${ }^{a^{*}}$, Sahameddin Mahmoudi Kurdistani ${ }^{\text {a }}$, Michele Palermo ${ }^{\text {a }}$, Dario Simoni ${ }^{\text {a }}$ \\ ${ }^{a}$ Department of Energy Engineering, Systems, Land and Construction, University of Pisa, Via Gabba \\ 22, 56122 Pisa, Italy
}

\begin{abstract}
Scour characteristics and morphologies downstream of rock sills due to channel curvature have been analyzed at the hydraulic laboratory of the University of Pisa. Two series of experiments have been conducted. The first series included tests on scour downstream of rock sills in straight channel. Three different channel bends with different lengths were studied in the second test series. All experiments have been carried out in clear water condition. The results showed that the tailwater depth plays an important role on scour characteristics. In addition, it was experimentally proven that the stream curvature affects the morphology and the maximum scour depth, i.e., an increase of the bend radius causes a decrease in the value of the maximum scour depth. Finally, three scour morphology types have been distinguished. Useful empirical relationships have been proposed in order to evaluate the main features of the scour geometry.
\end{abstract}

Keywords: Grade-control Structures; Hydraulic Structures; River Restoration; Rock Sill; Scour

\section{Introduction:}

The variation of flow conditions due to river bends or meanders can lead to riverbanks and structures failure, such as bridges, river passing pipelines, diversion dams, water intakes, and invert siphons. In-stream grade-control structures are used to stabilize riverbed, riverbanks, and improving aquatic habitat. Rock sills are in-stream structures commonly adopted to control stilling basins erosion and to protect river crossing structures.

Local scour processes and mechanisms are fundamental topics for river engineers. Among others, Schoklitsch 1932, Veronese 1937, Hassan and Narayanan 1985, Farhoudi and Smith 1985, Mason and Arumugam 1985, Bormann and Julien 1991, Whittaker and Jaggi 1996,

\footnotetext{
${ }^{*}$ Corresponding author. Present address: DESTEC-Department of Energy Engineering, Systems, Land and Construction, University of Pisa, Italy. Via Gabba 22, 56122 Pisa, Italy, Tel. +39 050 2217717; fax +39050 2217730, E-mail address: s.pagliara@ing.unipi.it
} 
Robinson et al. 1998, Dey and Sarkar 2006a, 2006b, 2008 gave important contributions on jet scour prediction and analysis.

Nevertheless, few experimental contributions, focused on grade-control structures, can be found in the literature. Przedwojski (1995) studied local scour process in rivers with banks protected by groynes. He showed that the depth of local scour varies with the groyne location. The maximum depth of local scour occurs at the groyne located downstream of the bend apex and it is significantly greater than the case of groynes installed at the entrance and the exit of the outer bank. Pagliara and Palermo (2008) and Pagliara et al. (2009) studied scour morphology downstream of block ramps, including the effect of protection sills in the stilling basin for different bed materials. Roca et al. (2007, 2009) showed that a well-designed horizontal foundation of the outer river bend, called footing, could protect vertical outer banks against erosion and at the same time reduce the scour depth. Bhuiyan et al. (2007) studied the flow turbulence characteristics and the scour development downstream of $\mathrm{W}$-weir at river bends in clear-water and live-bed conditions. Bhuiyan et al. (2010) carried out an experimental study on bank-attached vanes for bank erosion control and river meanders restoration. They showed that multiple vanes angled at $30^{\circ}$ to the bank line effectively relocate the deeper channel away from the outer bank in a bend.

Scurlock et al. (2012a) carried out experiments on the vane-dike in channel bends and derived a series of equations to estimate maximum flow velocities. Scurlock et al. (2012b) conducted an experimental study on scour downstream of in-stream structures designed by Rosgen (2001), like Cross-Vane structures and W-weirs in straight channels to estimate the maximum scour depth. Pagliara and Kurdistani (2013) carried out an experimental study on scour downstream of Cross-Vane structures for different bed slopes in straight channel and proposed equations to estimate the main scour parameters. Pagliara et al. (2013) studied the scour phenomenon downstream of J-Hook vane in straight rivers distinguishing three types of scour. Pagliara et al. (2014) conducted a series of experiments on scour downstream of Wweirs. They found that the tailwater depth plays an important role to predict the scour parameters. They carried out some tests with open $\mathrm{W}$-weir and showed that the maximum 
scour depth decreases and its location shifts downstream respect to the case of classical Wweir.

Jamieson et al. (2013a) studied the effects of stream barbs (spur dikes or submerged groynes) to redirect the high velocity core from the outer bank and prevent erosion of the flood plain at the bend exit. They demonstrated that the outer bank between barbs may still be at risk of erosion or even increase erosion as their size and layout generates excessive secondary velocities that are opposing the primary secondary flow naturally occurring in channel bends. Jamieson et al. (2013b) expanded their study on turbulence and vorticity in a channel bend at equilibrium clear-water scour in the presence and absence of stream barbs and they showed that local scour near the barbs was associated with increased z-vorticity. Recently Guan et al. (2014) conducted a series of experiments to investigate the flow patterns and turbulence in a scour hole downstream of a submerged weir. They showed that the turbulence structures ahead of the recirculation zone govern the dimensions of the scour hole.

The main objective of this contribution is to study the effect of the meander radius on the scour characteristics downstream of rock sills.

\section{Experimental Facilities:}

All the experiments were conducted in two channel setups made at the Hydraulic Laboratory of the University of Pisa. Channel setup I was used to study the scour parameters downstream of rock sills in straight channels and channel setup II was used to study the scour phenomena downstream of rock sills in curved channels. The experimental channel setup I included a horizontal rectangular channel $0.80 \mathrm{~m}$ wide, $20 \mathrm{~m}$ long and $0.75 \mathrm{~m}$ high. A tank supplied the approaching stable inflow. A standard weir measured the discharge with a precision of \pm 0.1 1/s. The water surface profiles and the morphology of the mobile bed have been surveyed using an ultrasonic distance measuring sensor with a precision of $0.001 \mathrm{~m}$.

The experimental setup II consisted in a curved channel $0.5 \mathrm{~m}$ wide, $15 \mathrm{~m}$ long and $0.5 \mathrm{~m}$ high (see Fig. 1). Three bends with different radius $(R=1,2$ and $4 \mathrm{~m})$ formed the channel. 
The curved parts of the model are separated by straight channels $2 \mathrm{~m}$ long in which grids are installed to straighten the approaching flow to the successive curve. Glass windows on the side walls enable to see the flow properties. An overhead tank supplied stable inflow. A magnetic current meter measured the discharge with precision of $\pm 0.01 \mathrm{l} / \mathrm{s}$. The water surface profiles were measured using a point gauge of reading accuracy of $\pm 0.0001 \mathrm{~m}$. At the end of each test, the bed morphology was surveyed using a Laser Scanner "HDS-4500 (Leica Geosystems)" with precision of $\pm 0.001 \mathrm{~m}$. Figure 2(a-c) shows the plan view of the straight and curved channels along with a stream wise view of the channel, including the main hydraulic and geometric parameters for Setup II (Fig. 2a) and Setup I (Fig. 2b), where $B$ is the channel width, $y_{0}$ is the approach flow depth, $\Delta y$ is the difference between water surface upstream and downstream of the structure, $z_{m}$ is the maximum depth of the scour hole, $l_{m}$ is the length of the scour hole in the longitudinal section in which the maximum scour depth occurs, $z_{m}^{\prime}$ is the maximum height of the ridge, $l_{m}^{\prime}$ is the ridge length in the longitudinal section in which the maximum ridge height occurs, $l$ is the length of the structure, $x_{m}$ is the longitudinal distance of maximum scour depth from the structure and $R$ is the curve radius.

Sills are constructed on a foundation made of bricks. Each structure contains three stone layers; $h_{s t}$ is the height of the sill defined as average top height of the stones above the original channel bed level.The design details of the rock arrangement are shown in Fig. 2(c). Experimental data are shown in Table 1, in which also the values of the densimetric particle Froude number $\mathrm{F}_{d}$ are reported.

It has to be noted that D'Agostino and Ferro (2004) adopted the parameter $A_{50}=$ $Q /\left\{l \cdot h_{s t} \cdot\left[g\left(G_{s}-1\right) d_{50}\right]^{0.5}\right\}$, for experimental test in which the length of the weir $(l)$ was equal or smaller than channel width $(B)$. Scurlock et al. (2012b) termed this parameter $\mathbf{F}_{d}$, as they studied localized scour phenomena downstream of weirs for which $l>B$. This parameter is widely adopted for scour related problems, as it takes into account both the geometric characteristics and hydraulic conditions which can cause the erosive process, representing the ratio of inertial to buoyancy forces. Namely, the densimetric particle Froude number is $\mathrm{F}_{d}=$ 
$Q /\left\{l \cdot h_{s t}\left[g\left(G_{s}-1\right) d_{50}\right]^{0.5}\right\}$ where $Q$ is the flow discharge, $G_{s}=\rho_{s} / \rho$, in which $\rho_{s}=$ bed material density and $\rho=$ water density, $d_{50}$ is the mean particle diameter and $g=$ gravitational acceleration. Uniform sand $\left(G_{s}=2.60, d_{50}=1.77 \mathrm{~mm}\right.$ and $\left.\sigma=\left(\mathrm{d}_{84} / \mathrm{d}_{16}\right)^{0.5}=1.26\right)$ was used as bed material. At the beginning of each experiment, the channel bed was carefully leveled. After each test the bed material was mixed in order to maintain the same gradation curve. Hager and Oliveto (2002) based on Shields' criterion, defined an inception Froude number to control the clear water condition which is considered in the current study.

In the tested range of parameters, after approximately 3 hours, no significant bed morphology variations occurred. This occurrence is also confirmed by Gaudio and Marion (2003) who analyzed the scour process evolution downstream of bed sills using a bed material whose granulometric characteristics $\left(d_{50}=1.8 \mathrm{~mm}, G_{s}=2.63\right)$ were practically the same of the material tested in the present study. They conducted experimental tests up to 90 hours showing that there is a negligible increase of the scour depth after approximately 3 hours. Therefore, in terms of practical applications, the morphology configuration reached after approximately 3 hours was assumed to be the equilibrium condition.

Two series of experiments were carried out. The first series includes tests on rock sills in straight channel while the second series contains the tests with rock sills in the meandering channel. The approaching flow Reynolds number was measured at the upstream of the each channel setup and varied between $31 \times 10^{3}$ and $181 \times 10^{3}$ for setup I and for setup II, indicating a turbulent flow condition for all the tests. All experiments were carried out in subcritical flow condition and in a few cases hydraulic jump occurred.

\section{Results and Discussion:}

Rock sills scour process is governed by the following functional relationship:

$f\left(z_{m}, h_{s t}, h_{t w}, l, B, \Delta y, Q, \rho_{s}, \rho, g, d_{50}, R\right)=0$ 
in which $f$ is a functional symbol. According to Pagliara and Kurdistani (2013), based on dimensional analysis and incomplete self-similarity (Barenblatt 1987), the following nondimensional functional expression can be derived from Eq. (1):

$z_{m} / h_{s t}=f^{\prime}\left(l / B, h_{t w} / h_{s t}, \mathrm{~F}_{d}, \Delta y / h_{s t}, B / R\right)$

Expression (2) contains all effective parameters on scour phenomena including structure geometry factors, densimetric Froude number, tailwater depth and channel curvature. It is clear that in straight channels (infinite radius), the term $B / R$ is zero, and equation is valid for straight channel. Functional relation (2) can be adopted also to determine the other scour parameters substituting $z_{m}$ with the corresponding variables in the dimensional analysis process.

\subsection{Scour Features and Morphologies:}

Scour and ridge formation process downstream of hydraulic structures is an important design feature. According to Pagliara and Kurdistani (2013), the scour parameter $\eta=\mathrm{F}_{d}^{2} \cdot \Delta y / h_{s t}$ was used to classify scour morphology for both straight $(0.01<\eta<60)$ and curved channels $(0.01$ $<\eta<20$ ). The effect of the channel curvature contributes to modify the scour geometry.

Figure 3 shows the maps derived by laser scanner readings for different morphologies. It can be noted that three types of scour morphologies take place. Type A morphology is characterized by scour holes and unique dune formed in the entire width of the channel. Figure 3a shows morphology Type A for straight channel named as Type $\mathrm{S}_{\mathrm{s}}-\mathrm{A}$, which indicates morphology Type A for sills in straight channels. Figure $3 \mathrm{~b}$ illustrates the

morphology Type A for curved channel with specific name Type $S_{c}-A$, where letter "c" corresponds to the curved channel. Figure 3c shows morphology Type B that the dune forms along with the scour hole, starting from internal bank of the channel and developing towards the channel outer bend (named as Type $\mathrm{S}_{\mathrm{c}}-\mathrm{B}$, which means morphology Type B for sills in curved channel). Figure $3 \mathrm{~d}$ reports the morphology Type $\mathrm{C}$ that the dune forms along with the scour hole and develops completely along the channel internal bend (Type $\mathrm{S}_{\mathrm{c}}-\mathrm{C}$ ) and indicates 
morphology Type $\mathrm{C}$ downstream of sills in curved channel. As the approaching flow condition is very important for the scour formation downstream of in-stream structures, special tests were conducted to clarify the effect of the sill position on scour morphology. Figure 4 compares two experiments in curved channel with external radius equals to $2 \mathrm{~m}$ for the same hydraulic conditions and tailwater $\left(\eta=4.45, h_{t w} / h_{s t}=1.8\right)$. Namely, Fig. 4a reports the scour morphology in the presence of a sill located at the beginning of the curve $\left(1^{\text {st }}\right.$ sill position), whereas Fig. $4 \mathrm{~b}$ shows the same for a sill located at the center of the curve $\left(2^{\text {nd }}\right.$ sill position). In particular, Fig. 4 shows that the scour hole extension at the external bend and the morphology type changes from Type $\mathrm{S}_{\mathrm{c}}-\mathrm{A}$ to Type $\mathrm{S}_{\mathrm{c}}-\mathrm{B}$ due to different sill location.

All experimental data were classified and plotted in a parametric graph $R / h_{t w}$ vs $\eta$ as shown in Fig. 5. It is evident that the increase of $R$ determines a transition from scour type $\mathrm{S}_{\mathrm{c}}-\mathrm{C}$ to scour type $\mathrm{S}_{\mathrm{c}}-\mathrm{A}$. In addition, it can be also noted that the morphology varies from Type $\mathrm{S}_{\mathrm{c}}-\mathrm{A}$ to Type $\mathrm{S}_{\mathrm{c}}-\mathrm{C}$ increasing $\eta$ and tailwater.

Pagliara and Kurdistani (2013) defined three types of morphologies downstream of rock sills (Cross-Vane with $l / B=1$ ): Type 1, i.e., long scour-long ridge; Type 2, i.e., short scour-long ridge; and Type 3, i.e., short scour-short ridge. Furthermore, in the case of straight channel ( $R$ $\rightarrow \infty$ ), the morphology Type $\mathrm{S}_{\mathrm{s}}$-A occurs. In other words, the three morphology types defined by Pagliara and Kurdistani (2013) are belonging to morphology Type $\mathrm{S}_{\mathrm{s}}-\mathrm{A}$, and the main parameter influencing scour typology is the channel curvature. Figure 6 shows a short scour short ridge morphology downstream of rock sill in straight channel during a test. The formation of scour Type $\mathrm{S}_{\mathrm{c}}-\mathrm{A}$ in curved channel with $R=1 \mathrm{~m}$ is shown in Fig. 7.

\subsection{Maximum Scour Depth:}

Pagliara and Kurdistani (2013), based on dimensional analysis and experimental data, found that the maximum scour depth can be expressed by Eq. (3), for $0.05<\eta<15$ and $h_{t w} / h_{s t}=1$ :

$$
z_{m} / h_{s t}=1.3\left[(l / B) \cdot\left(1+S_{0}^{0.1}\right)\right]^{0.9} \eta^{0.4}
$$


Where $S_{0}$ is the channel bed slope, which is equal to zero in current study. For rock sill $l / B=$ 1, Eq. (3) can be re-written as follows:

$z_{m} / h_{s t}=1.3 \eta^{0.4}$

Based on both Eq. (2) and current experimental data, including the effect of the parameter $h_{t w} / h_{s t}$ for straight channel, Eq. (5) $\left(\mathrm{R}^{2}=0.79\right)$ has been derived:

$z_{m} / h_{s t}=1.3 \cdot\left(h_{t w} / h_{s t}\right)^{-1.7} \eta^{0.4}$

It is valid for $0.01<\eta<60$. Note that Eq. (5) coincides with Eq. (4) for $h_{t w} / h_{s t}=1$. Figure 8 shows experimental data with the indication of $h_{t w} / h_{s t}$ values, along with plots of Eq. (5) for selected different $h_{t w} / h_{s t}$. It can be observed that $z_{m} / h_{s t}$ decreases with $h_{t w} / h_{s t}$ for constant $\eta$.

Investigation on observed data in curved channel showed that both the curvature of the channel and tailwater are influencing maximum scour depth values. In addition, data analysis allowed to state that the position of the sill is not significantly affecting scour depth but just morphology types. Therefore the non-dimensional parameter $\psi=1+(B / R)^{0.5}$ has been introduced and Eq. (5) has been modified in order to account curvature effect. The following Eq. (6) was found able to predict the totality of data:

$z_{m} / h_{s t}=1.3 \cdot \psi^{2} \cdot\left(h_{t w} / h_{s t}\right)^{-1.7 \psi^{0.3}} \eta^{0.4^{\psi}}$

Note that for straight channels $R \rightarrow \infty$ and $\psi \approx 1$, thus Eq. (6) coincides with Eq. (5). The predicting capability of Eq. (6) is shown in Fig. 9, in which all experimental data (including those relative to straight channel) are taken into consideration. Figure 9 shows positions of all data respect with the lines of $30 \%$ deviation from the perfect agreement line. It shows that only few points are slightly out of this range. The effects of both $h_{t w} / h_{s t}$ and $B / R$ on $z_{m} / h_{s t}$ are shown in Fig. 10a-b. Equation (6) plots for curved channel $(R=4 \mathrm{~m})$ and selected values of tailwater $h_{t w} / h_{s t}$ is compared in Fig. 10a. It can be noted that the maximum scour depth decreases with tailwater.

The effect of the parameter $B / R$ was also put in evidence. Namely, Fig. 10b shows the effect of $B / R$ on scour depth for a fixed $h_{t w} / h_{s t}=2.5$. It can be observed that the maximum scour 
depth increases with $B / R$, whereas if $R$ increases the curves tend to that relative to straight channel. It has to be noted that, due to the secondary current flows at the channel bend, the location of the maximum scour depth occurs close to the outer bend and scour depth increases during experimental tests. Therefore, there is a significant effect of channel curvature on the maximum scour depth value. Conversely, as it will be shown in the following sections, the other scour parameters (i.e., maximum scour length, maximum height and length of the dune) are mainly influenced by hydraulic conditions and tailwater depth. In fact, the sediment transport and deposit downstream of the scour hole mainly depend on hydraulic parameters and the effect of curvature plays a minor role.

\subsection{Scour Hole Length:}

The length of the scour hole $l_{m}$ is another important design feature for in-stream structures. Pagliara and Kurdistani (2013) presented an expression to determine the maximum scour length downstream of cross-vane structures for $0.05<\eta<15$ as follows:

$l_{m} / h_{s t}=8.8\left[(l / B) \cdot\left(1-S_{0}^{0.4}\right)\right]^{1.9} \eta^{0.6}$

As the $1^{\text {st }}$ series of the current experiments were conducted in a horizontal straight channel and $l / B=1$ for rock sills, Eq. (7) $\left(\mathrm{R}^{2}=0.85\right)$ can be re-written as follows and it is valid in the range $0.5<h_{t w} / h_{s t} \leq 3$ :

$l_{m} / h_{s t}=8.8 \eta^{0.6}$

Figure 11 reports all the experimental observations relative to both straight and curved channels. It shows that, in the specified range of parameters, the effect of channel curvature on scour hole length is negligible, as previously mentioned. Thus, for both curved and straight channels, Eq. (8) is valid.

\subsection{Location of the Maximum Scour:}

The analysis of experimental data shows that channel curvature effect on maximum scour depth location $x_{m}$ is negligible. Data relative to both straight and curved channels were plotted in a graph $x_{m} / h_{s t}$ vs $\eta$ (see Fig. 12). It can be observed that they exhibit the same trend, thus 
one single equation $\left(\mathrm{R}^{2}=0.75\right)$ was derived to predict the totality of experimental data as follows:

$x_{m} / h_{s t}=2.5 \eta^{0.4}$

\subsection{Maximum Height of the Dune:}

Another important morphology feature is the dune geometry. In addition, also in this case, the analysis of data showed that the channel curvature effect on the maximum ridge height is negligible. Experimental results, including both straight and curved channels, data are shown in Fig. 13. It can be noted that $h_{t w} / h_{s t}$ is the only parameter affecting maximum ridge height. This phenomenon could be expressed by Eq. (10) $\left(\mathrm{R}^{2}=0.71\right)$, valid for $0.5<h_{t w} / h_{s t}<4$, as follows:

$z_{m}^{\prime} / h_{s t}=1.05 \cdot\left(h_{t w} / h_{s t}\right)^{-1.25} \eta^{0.4}$

Equation (10) is compared with experimental data in Fig. 13. Namely, Eq. (10) was plotted for selected $h_{t w} / h_{s t}$ values $\left(h_{t w} / h_{s t}=0.75,1.25,2.5\right)$. It can be noted that the proposed equation well predicts the totality of data.

\subsection{Maximum Length of the Dune:}

The length of the dune $l_{m}^{\prime}$ was analysed too. Figure 14 shows that there is no significant effect of channel curvature and tailwater ratio. In fact, for both straight and curved channels, experimental data exhibit the same trend which can be represented by the following equation $\left(\mathrm{R}^{2}=0.93\right)$ :

$l_{m}^{\prime} / h_{s t}=7 \eta^{0.4}$

\section{Conclusion:}

Two series of experiments were conducted to investigate the scour morphology downstream of rock sills. The first series of experiments were conducted in a straight horizontal channel and the second series of experiments in a meandering channel. Based on dimensional analysis, novel empirical relationships were found to predict the maximum scour depth for 
different combinations of hydraulic conditions, channel curvature and structures geometry. Densimetric Froude number, drop height, tailwater and height of the structure are the main parameters influencing the maximum scour depth, the maximum scour length, the location of the maximum scour depth, maximum ridge height and the maximum ridge length. Results showed that a classification of scour types can be proposed depending on the non-dimensional parameters $R / h_{t w}, h_{t w} / h_{s t}$ and $\eta$. Scour typologies included three types of morphologies termed as Type $\mathrm{S}_{\mathrm{c}}-\mathrm{A}$, Type $\mathrm{S}_{\mathrm{c}}-\mathrm{B}$ and Type $\mathrm{S}_{\mathrm{c}}-\mathrm{C}$. The increase of the channel curvature modifies the scour morphology from Type $\mathrm{S}_{\mathrm{c}}-\mathrm{C}$ to Type $\mathrm{S}_{\mathrm{c}}-\mathrm{B}$ and finally Type $\mathrm{S}_{\mathrm{c}}-\mathrm{A}$.

\section{Notation}

$A_{50}=$ dimensionless parameter associated to grain size $d_{50}$

$B$ = channel width (m)

$d_{50}=$ mean particle diameter $(\mathrm{m})$

$f=$ functional symbol (-)

$f^{\prime}=$ functional symbol (-)

$\mathrm{F}_{d}=$ densimetric Froude number $=Q /\left\{l \cdot h_{s t}\left[g\left(G_{s}-1\right) d_{50}\right]^{0.5}\right\}(-)$

$g=$ gravity acceleration $\left(\mathrm{ms}^{-2}\right)$

$G_{s}=\rho_{s} / \rho(-)$

$h_{s t}=$ height of the structure (average height of the stones) (m)

$h_{t w}=$ tailwater depth (m)

$l \quad=$ length of the structure $(\mathrm{m})$

$l_{m}=$ scour length downstream of the structure (m)

$l_{m}^{\prime}=$ ridge length $(\mathrm{m})$

$Q=$ flow discharge $\left(\mathrm{m}^{3} \mathrm{~s}^{-1}\right)$

$R=$ channel bend radius $(\mathrm{m})$

$S_{0}=$ channel bed slope (-)

$x_{m}=$ location of the maximum scour depth (m)

$y_{0}=$ approach flow depth $(\mathrm{m})$

$z_{m}=$ maximum scour depth downstream of the structure (m) 
$z_{m}^{\prime}=$ maximum ridge height $(\mathrm{m})$

$\Delta y=$ difference between water surface upstream and downstream of the structure $(\mathrm{m})$

$\eta \quad=\mathrm{F}_{d}^{2} \cdot \Delta y / h_{s t}(-)$

$\rho \quad=$ water density $\left(\mathrm{kgm}^{-3}\right)$

$\rho_{s} \quad=$ bed material density $\left(\mathrm{kgm}^{-3}\right)$

$\sigma \quad=$ particle uniformity factor $=\left(\mathrm{d}_{84} / \mathrm{d}_{16}\right)^{0.5}(-)$

$\psi \quad=1+(B / R)^{0.5}(-)$

\section{References}

Barenblatt, G. I. (1987), Dimensional Analysis, Gordon and Breach Science Publishers, ISBN 3-7186-0438-8.

Bhuiyan, F., Hey, R. D., Wormleaton, P. R. (2007). Hydraulic Evaluation of W-Weir for River Restoration, J. Hydraulic Eng. 133(6), 596-609.

Bhuiyan, F., Hey, R. D., Wormleaton, P. R. (2010). Bank-Attached Vanes for Bank Erosion Control and Restoration of River Meanders, J. Hydraulic Eng. 136(9), 583-596.

Bormann, N. E., Julien, P. Y. (1991), Scour Downstream of Grade-Control Structures, J. Hydraulic Eng. 117(5), 579-594.

D'Agostino, V. and Ferro, V. (2004). Scour on Alluvial Bed Downstream of Grade-Control Structures, J. Hydraulic Eng. 130(1), 24-37.

Dey, S., Sarkar A. (2006a). Scour downstream of an apron due to submerged horizontal jets, J. Hydraulic Eng. 132(3), 246-257.

Dey, S., Sarkar A. (2006b). Response of velocity and turbulence in submerged wall jets to abrupt changes from smooth to rough beds and its application to scour downstream of an apron, J. Fluid Mech. 556, 387-419.

Dey, S., Sarkar A. (2008), Characteristics of submerged jets in evolving scour hole downstream of an apron, J. Eng. Mech. 134(11), 927-936.

Farhoudi, J., Smith, K.V.H. (1985). Local scour profile downstream of hydraulic jump, $J$. Hydraulic Res. 23(4), 343-358.

Guan, D., Melville, B., Friedrich, H. (2014). Flow Patterns and Turbulence Structures in a Scour Hole Downstream of a Submerged Weir, J. Hydraulic Eng., 140(1), 68-76.

Gaudio, R. and Marion, A. (2003). Time evolution of scouring downstream of bed sills, $J$. Hydraulic Res. 41(3), 271-284.

Hager, W. H., Oliveto, G. (2002). Shields' Entrainment Criterion in Bridge Hydraulics, $J$. Hydraulic Eng. 128(5), 538-542. 
Hassan, N. M. K. N., Narayanan, R. (1985). Local scour downstream of an apron, $J$. Hydraulic Eng. 111(11), 1371-1385.

Jamieson, E. C., Rennie, C. D., Townsend, R. D. (2013a). 3D flow and sediment dynamics in a laboratory channel bend with and without stream barbs, J. Hydraulic Eng. 139(2), 154-166.

Jamieson, E. C., Rennie, C. D., Townsend, R. D. (2013b). Turbulence and Vorticity in a Laboratory Channel Bend at Equilibrium Clear-Water Scour with and without Stream Barbs, J. Hydraulic Eng. 139(3), 259-268.

Mason, P. J. and Arumugam, K. (1985). Free Jet Scour Below Dams and Flipbuckets, J. Hydraulic Eng. 111(2), 220-235.

Pagliara, S., Kurdistani, S.M. (2013). Scour downstream of cross-vane structures, J. HydroEnvir. Res. 7(4), 236-242.

Pagliara, S., Kurdistani, S. M., Santucci, I. (2013). Scour Downstream of J-Hook Vanes in Straight Horizontal Channels, Acta Geophysica 61(5), 1211-1228.

Pagliara, S., Kurdistani, S. M., Cammarata, L. (2014). Scour of Clear Water Rock W-Weirs in Straight Rivers, J. Hydraulic Eng. 140(4), 06014002.

Pagliara, S., Palermo, M. (2008). Scour control and surface sediment distribution downstream of block ramps, J. Hydraulic Res. 46(3), 334-343.

Pagliara, S., Palermo M., Carnacina, I. (2009). Scour and hydraulic jump downstream of block ramps in expanding stilling basins, J. Hydraulic Res. 47(4), 503-511.

Przedwojski, B. (1995). Bed topography and local scour in rivers with banks protected by groynes, J. Hydraulic Res. 33(2), 257-273.

Robinson, K. M., Rice, C. E., Kadavy, K. C. (1998). Design of rock chutes, American Society of Agricultural Engineers 41(3), 621-626.

Roca, M., Martín-Vide, J. P., Blanckaert, K. (2007). Reduction of bend scour by an outer bank footing: Footing design and bed topography, J. Hydraulic Eng. 133(2), 139-147.

Roca, M., Blanckaert, K., Martín-Vide, J. P. (2009). Reduction of bend scour by an outer bank footing: Flow Field and Turbulence, J. Hydraulic Eng. 135(5), 361-368.

Rosgen, D.L. (2001). The Cross-Vane, W-weir and J-Hook Vane Structures: Their Description, Design and Application for Stream Stabilization and River Restoration, paper presented at Conference on Wetland Engineering and River Restoration, Proc., Wetland Engineering and River Restoration Conf. (CD-ROM), ASCE, Reston, Va.

Schoklitsch, A. (1932), Kolkbildung unter Uberfallstrahlen, Wasserwirstchaft, 25(24), 341343 (in German).

Scurlock, S.M., Cox, A. L., Thornton, C. I. Baird, D. C. (2012a). Maximum Velocity Effects from Vane-Dike Installations in Channel Bends, Proceedings of World Environmental and Water Resources Congress 2012: Crossing Boundaries, 2614-2626. 
Scurlock, S.M., Thornton,C. I., , Abt S. R. (2012b). Equilibrium Scour Downstream of Threedimensional Grade-control Structures, J. Hydraulic Eng. 138(2), 167-176.

Veronese, A. (1937). "Erosioni di fondo a valle di uno scarico." Annali dei Lavori Pubblici, 75(9), 717-726 (in Italian).

Whittaker, W., and Jaggi, M. (1996), Blockshwellen, Mitteilungen 91, Versuchsanstalt fur Wasserbrau, Hydrologie und Glaziologie, ETH, Zurich, Switzerland (in German). 
Table 1 Experimental data

\begin{tabular}{|c|c|c|c|c|c|c|c|c|}
\hline Test No. & $Q\left(\mathrm{~m}^{3} \mathrm{~s}^{-1}\right)$ & $B / R(-)$ & $\Delta y(\mathrm{~m})$ & $h_{s t}(\mathrm{~m})$ & $h_{t w}(\mathrm{~m})$ & $\mathrm{F}_{d}(-)$ & $z_{m}(\mathrm{~m})$ & $\begin{array}{l}z_{m}^{\prime} \\
(\mathrm{m})\end{array}$ \\
\hline 1 & 0.0140 & 0.500 & 0.007 & 0.029 & 0.112 & 5.79 & 0.026 & 0.021 \\
\hline 2 & 0.0140 & 0.500 & 0.011 & 0.029 & 0.089 & 5.79 & 0.049 & 0.047 \\
\hline 3 & 0.0160 & 0.500 & 0.011 & 0.029 & 0.099 & 6.62 & 0.050 & 0.040 \\
\hline 4 & 0.0020 & 0.500 & 0.025 & 0.054 & 0.047 & 0.44 & 0.038 & 0.030 \\
\hline 5 & 0.0180 & 0.500 & 0.010 & 0.030 & 0.112 & 7.45 & 0.045 & 0.046 \\
\hline 6 & 0.0030 & 0.500 & 0.022 & 0.050 & 0.050 & 0.67 & 0.042 & 0.040 \\
\hline 7 & 0.0200 & 0.250 & 0.015 & 0.050 & 0.108 & 4.73 & 0.070 & 0.045 \\
\hline 8 & 0.0200 & 0.250 & 0.016 & 0.050 & 0.107 & 4.73 & 0.074 & 0.038 \\
\hline 9 & 0.0150 & 0.250 & 0.010 & 0.050 & 0.104 & 3.55 & 0.041 & 0.018 \\
\hline 10 & 0.0140 & 0.250 & 0.003 & 0.029 & 0.106 & 5.79 & 0.018 & 0.011 \\
\hline 11 & 0.0140 & 0.250 & 0.006 & 0.029 & 0.092 & 5.79 & 0.027 & 0.016 \\
\hline 12 & 0.0180 & 0.250 & 0.003 & 0.029 & 0.126 & 7.45 & 0.017 & 0.014 \\
\hline 13 & 0.0180 & 0.250 & 0.009 & 0.029 & 0.100 & 7.45 & 0.050 & 0.036 \\
\hline 14 & 0.0200 & 0.250 & 0.004 & 0.029 & 0.126 & 8.28 & 0.020 & 0.022 \\
\hline 15 & 0.0200 & 0.250 & 0.008 & 0.029 & 0.110 & 8.28 & 0.047 & 0.041 \\
\hline 16 & 0.0080 & 0.250 & 0.009 & 0.054 & 0.078 & 1.78 & 0.033 & 0.030 \\
\hline 17 & 0.0020 & 0.250 & 0.022 & 0.052 & 0.039 & 0.46 & 0.044 & 0.029 \\
\hline 18 & 0.0200 & 0.125 & 0.007 & 0.050 & 0.093 & 4.73 & 0.082 & 0.035 \\
\hline 19 & 0.0150 & 0.125 & 0.012 & 0.050 & 0.076 & 3.55 & 0.076 & 0.024 \\
\hline 20 & 0.0180 & 0.125 & 0.011 & 0.050 & 0.101 & 4.25 & 0.064 & 0.022 \\
\hline 21 & 0.0100 & 0.125 & 0.010 & 0.050 & 0.071 & 2.36 & 0.043 & 0.029 \\
\hline 22 & 0.0050 & 0.125 & 0.014 & 0.050 & 0.058 & 1.18 & 0.035 & 0.032 \\
\hline 23 & 0.0120 & 0.125 & 0.003 & 0.029 & 0.080 & 4.97 & 0.027 & 0.011 \\
\hline 24 & 0.0140 & 0.125 & 0.004 & 0.029 & 0.093 & 5.79 & 0.024 & 0.015 \\
\hline 25 & 0.0140 & 0.125 & 0.007 & 0.029 & 0.080 & 5.79 & 0.045 & 0.031 \\
\hline 26 & 0.0160 & 0.125 & 0.003 & 0.029 & 0.111 & 6.62 & 0.014 & 0.016 \\
\hline 27 & 0.0160 & 0.125 & 0.005 & 0.029 & 0.101 & 6.62 & 0.027 & 0.027 \\
\hline 28 & 0.0180 & 0.125 & 0.003 & 0.029 & 0.126 & 7.45 & 0.013 & 0.030 \\
\hline 29 & 0.0180 & 0.125 & 0.004 & 0.029 & 0.111 & 7.45 & 0.026 & 0.022 \\
\hline 30 & 0.0200 & 0.125 & 0.005 & 0.029 & 0.120 & 8.28 & 0.027 & 0.025 \\
\hline 31 & 0.0200 & 0.125 & 0.007 & 0.029 & 0.108 & 8.28 & 0.042 & 0.035 \\
\hline 32 & 0.0080 & 0.125 & 0.009 & 0.054 & 0.079 & 1.78 & 0.035 & - \\
\hline 33 & 0.0030 & 0.125 & 0.011 & 0.054 & 0.053 & 0.67 & 0.036 & 0.039 \\
\hline 34 & 0.0500 & 0.000 & 0.015 & 0.090 & 0.166 & 4.24 & 0.073 & 0.037 \\
\hline 35 & 0.0300 & 0.000 & 0.003 & 0.090 & 0.152 & 2.55 & 0.039 & 0.022 \\
\hline 36 & 0.0300 & 0.000 & 0.006 & 0.090 & 0.144 & 2.55 & 0.049 & 0.010 \\
\hline 37 & 0.0076 & 0.000 & 0.010 & 0.040 & 0.044 & 1.46 & 0.041 & 0.025 \\
\hline 38 & 0.0076 & 0.000 & 0.018 & 0.040 & 0.041 & 1.46 & 0.054 & 0.034 \\
\hline 39 & 0.0115 & 0.000 & 0.017 & 0.040 & 0.043 & 2.19 & 0.080 & - \\
\hline 40 & 0.0050 & 0.000 & 0.025 & 0.032 & 0.022 & 1.20 & 0.072 & - \\
\hline 41 & 0.0200 & 0.000 & 0.025 & 0.060 & 0.092 & 2.55 & 0.101 & 0.032 \\
\hline 42 & 0.0100 & 0.000 & 0.031 & 0.060 & 0.061 & 1.27 & 0.103 & 0.041 \\
\hline 43 & 0.0050 & 0.000 & 0.011 & 0.060 & 0.058 & 0.64 & 0.033 & 0.031 \\
\hline 44 & 0.0150 & 0.000 & 0.029 & 0.060 & 0.059 & 1.91 & 0.123 & - \\
\hline 45 & 0.0250 & 0.000 & 0.026 & 0.060 & 0.080 & 3.18 & 0.106 & 0.032 \\
\hline 46 & 0.0200 & 0.000 & 0.025 & 0.079 & 0.092 & 1.94 & 0.082 & 0.051 \\
\hline 47 & 0.0160 & 0.000 & 0.002 & 0.079 & 0.115 & 1.55 & 0.022 & 0.014 \\
\hline 48 & 0.0500 & 0.000 & 0.013 & 0.032 & 0.141 & 12.00 & 0.027 & 0.060 \\
\hline 49 & 0.0020 & 0.000 & 0.007 & 0.030 & 0.031 & 1.95 & 0.037 & 0.019 \\
\hline 50 & 0.0030 & 0.000 & 0.004 & 0.030 & 0.031 & 2.92 & 0.039 & 0.027 \\
\hline 51 & 0.0020 & 0.000 & 0.004 & 0.030 & 0.031 & 1.95 & 0.030 & 0.017 \\
\hline 52 & 0.0030 & 0.000 & 0.008 & 0.030 & 0.032 & 2.92 & 0.054 & - \\
\hline 53 & 0.0020 & 0.000 & 0.003 & 0.020 & 0.031 & 2.92 & 0.021 & 0.008 \\
\hline 54 & 0.0030 & 0.000 & 0.003 & 0.020 & 0.025 & 4.38 & 0.039 & - \\
\hline 55 & 0.0020 & 0.000 & 0.010 & 0.040 & 0.041 & 1.46 & 0.041 & 0.025 \\
\hline 56 & 0.0020 & 0.000 & 0.018 & 0.040 & 0.038 & 1.46 & 0.054 & - \\
\hline 57 & 0.0030 & 0.000 & 0.012 & 0.040 & 0.042 & 2.19 & 0.070 & - \\
\hline 58 & 0.0030 & 0.000 & 0.017 & 0.040 & 0.037 & 2.19 & 0.080 & - \\
\hline
\end{tabular}




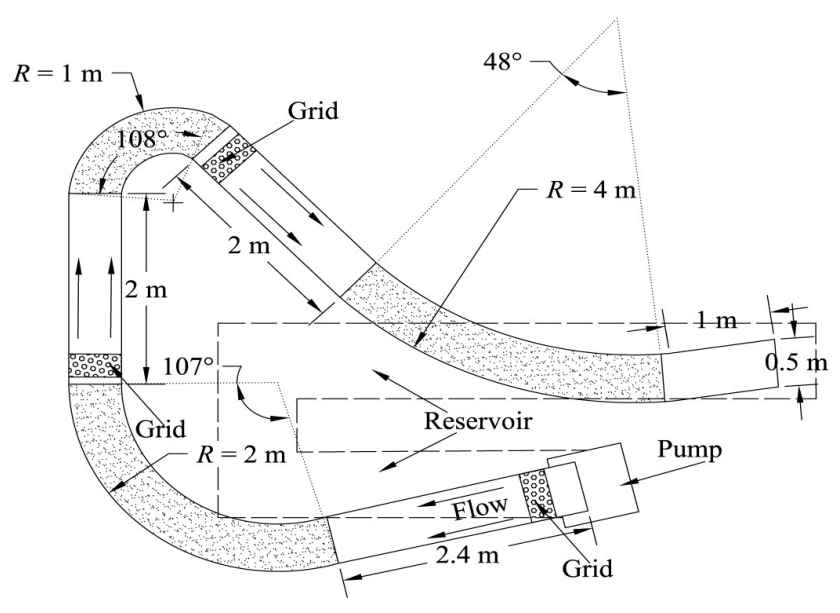

Figure 1 Diagram sketch of the channel setup II.

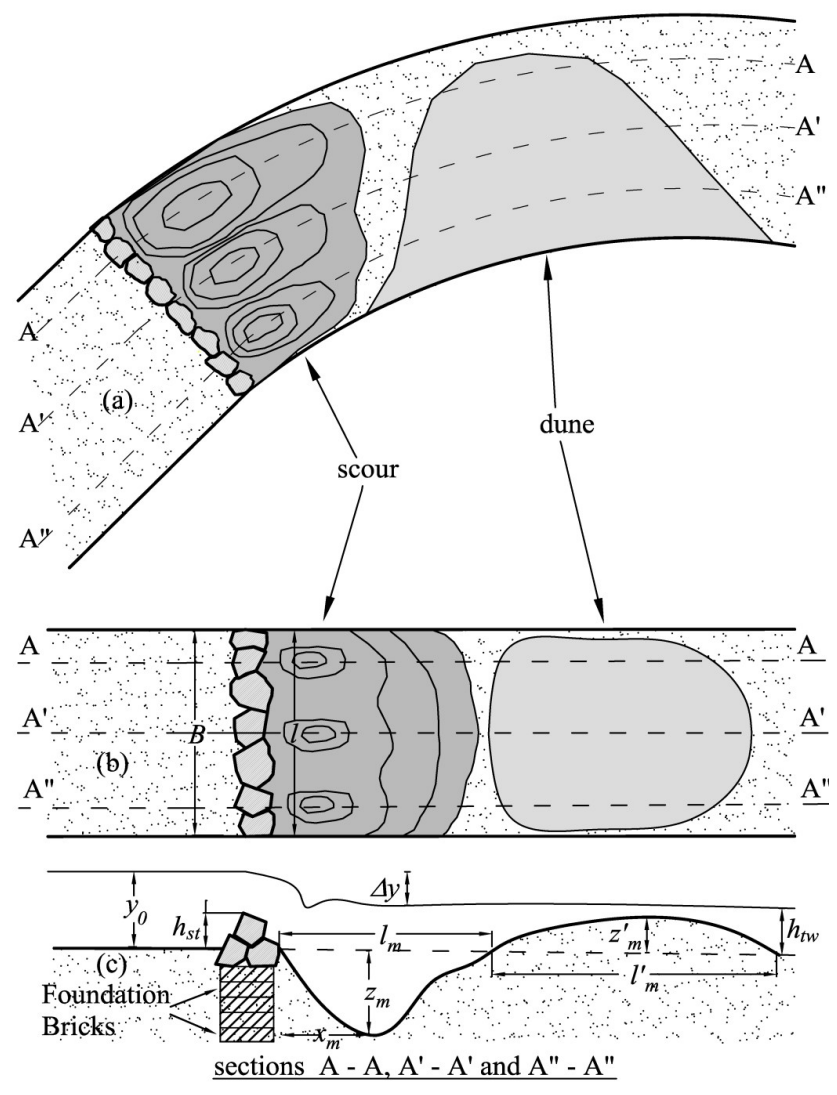

Figure 2 a) Plan view of (a) channel setup II and (b) channel setup I; c) stream wise view of the scour and dune morphology. 

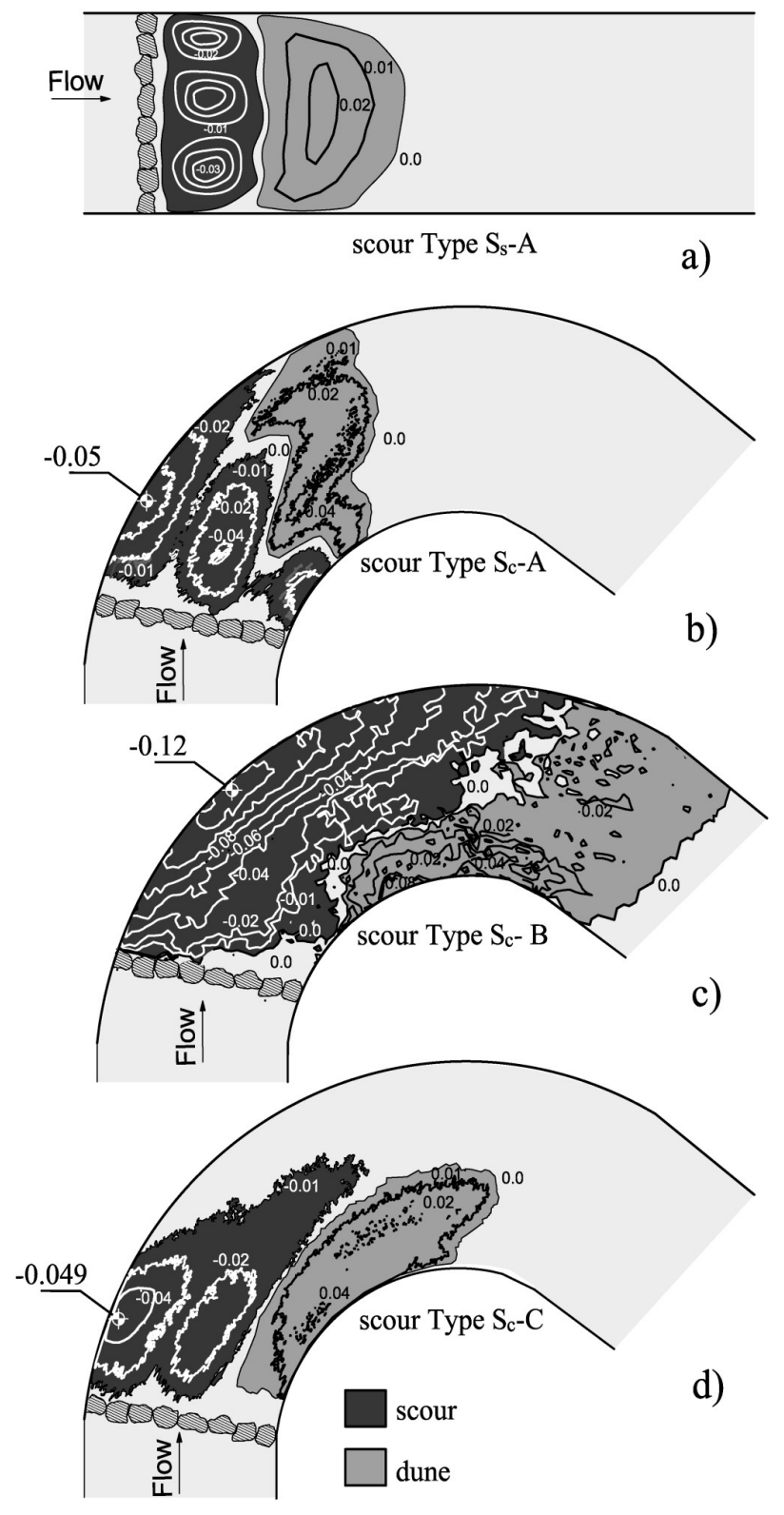

Figure 3 a) Morphology Type $S_{s}-A$, b) Morphology Type $S_{c}-A$, c) Morphology Type $S_{c}-B$ and d) Morphology Type $\mathrm{S}_{\mathrm{c}}-\mathrm{C}$ (scour/deposition values are in meters). 


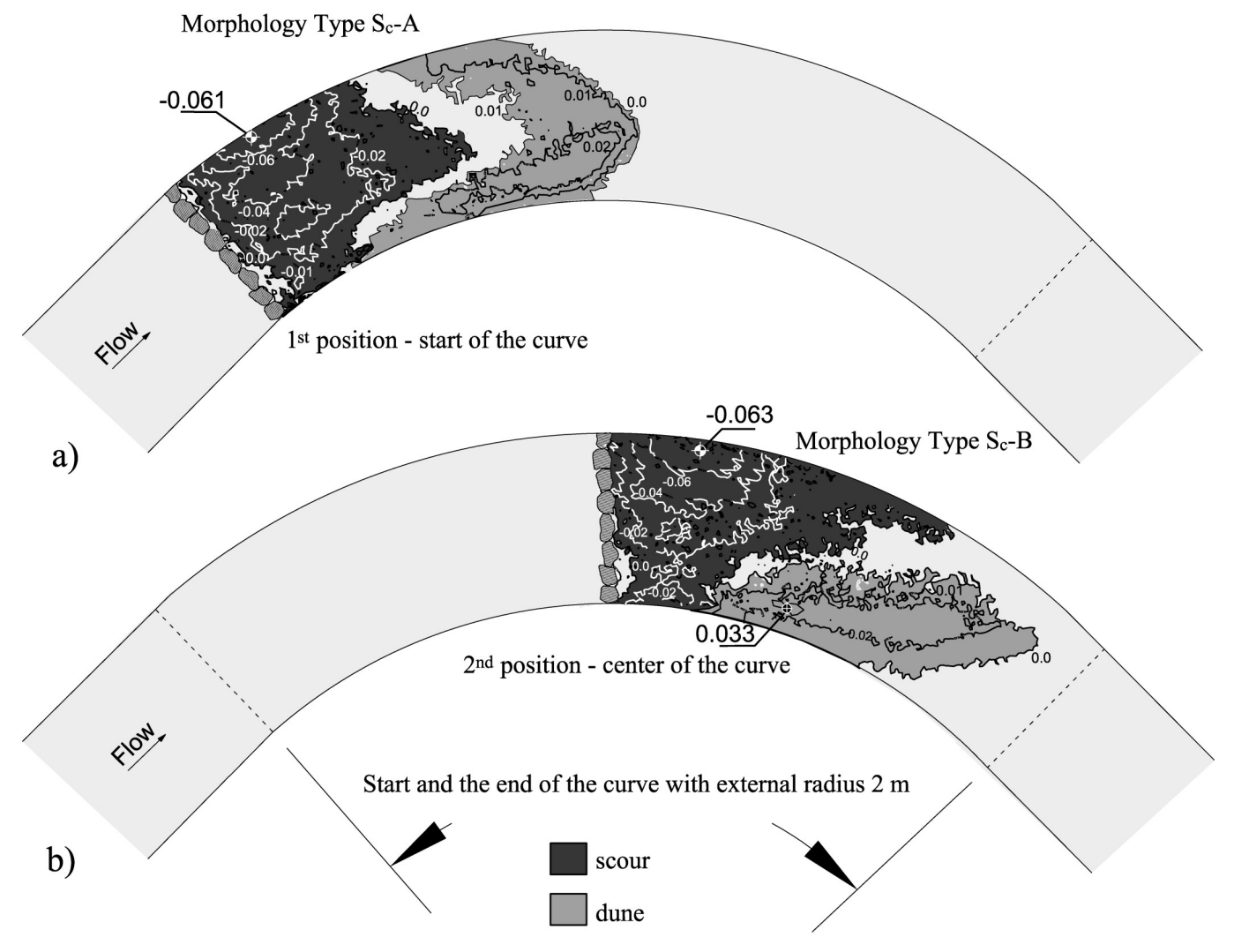

Figure 4 Morphology types downstream of rock sills for $\eta=4.45, h_{t w} / h_{s t}=1.8$ and for a) $1^{\text {st }}$ sill position (beginning of the curve) and b) $2^{\text {nd }}$ sill position (center of the curve) (scour/deposition values are in meters).

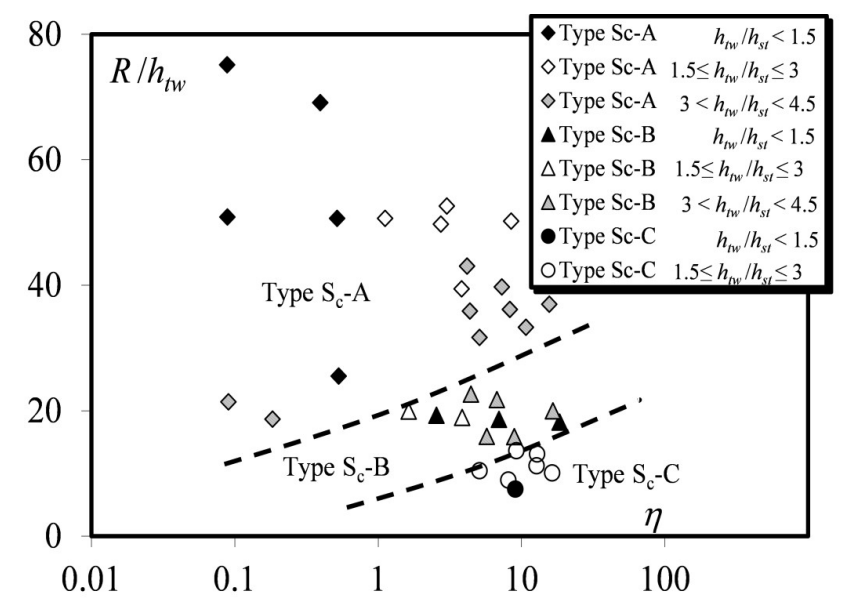

Figure 5 Scour typologies classification. 


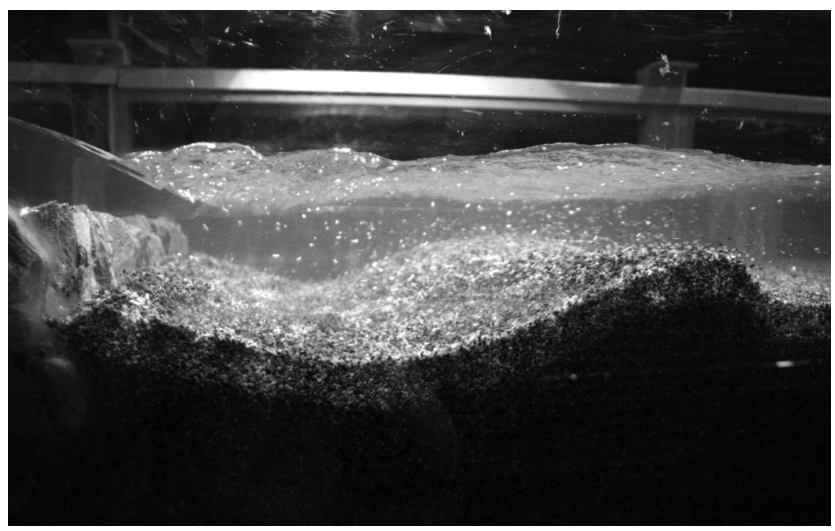

Figure 6 Picture of scour Type $\mathrm{S}_{\mathrm{s}}-\mathrm{A}$ (short scour - short ridge) in straight channel during a test.

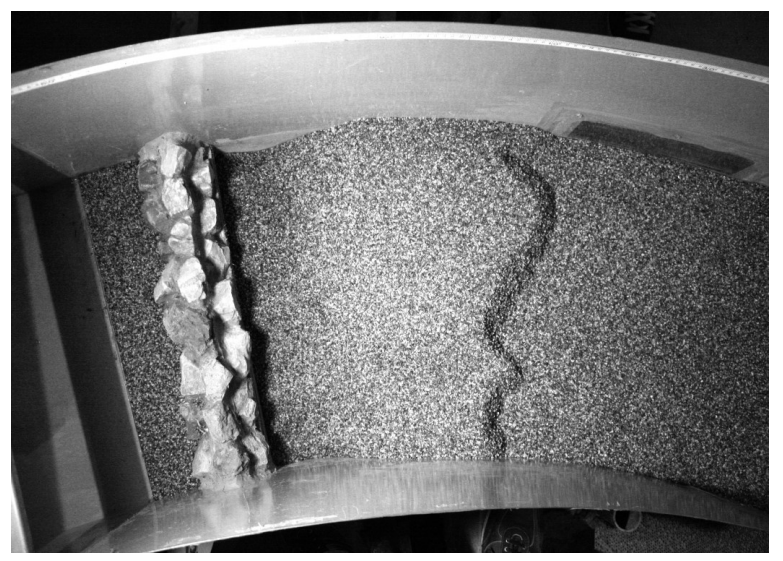

Figure 7 Picture of scour Type $\mathrm{S}_{\mathrm{c}}-\mathrm{A}$ in curved channel with $R=1 \mathrm{~m}$.

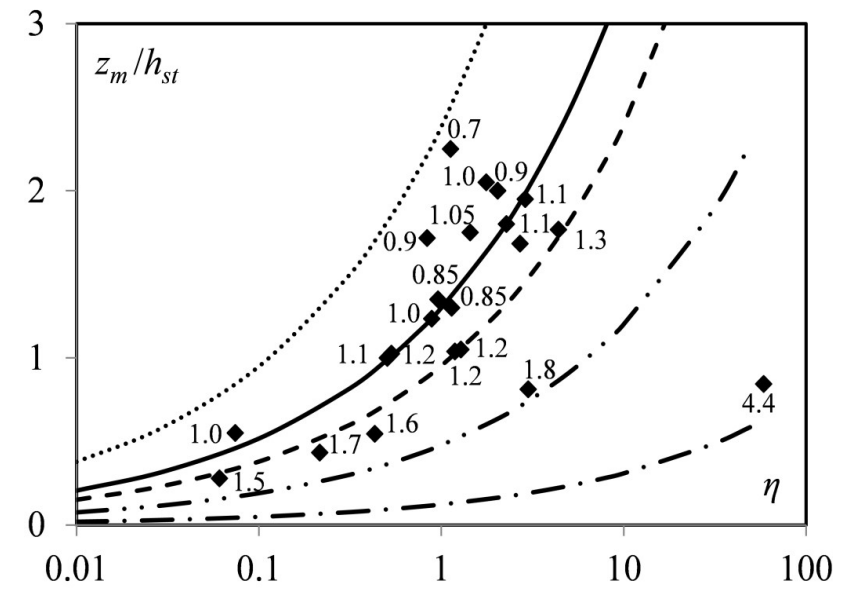

Figure 8 Comparison of experimental data with Eq. (5) in straight channel for $h_{t w} / h_{s t}=0.7$ $[\cdots \cdots \cdot], h_{t w} / h_{s t}=1.0[-], h_{t w} / h_{s t}=1.2[-------], h_{t w} / h_{s t}=1.8[-\cdot \cdot-\cdot-], h_{t w} / h_{s t}=4.0$ $[-\cdot-\cdot-\cdot-]$. 


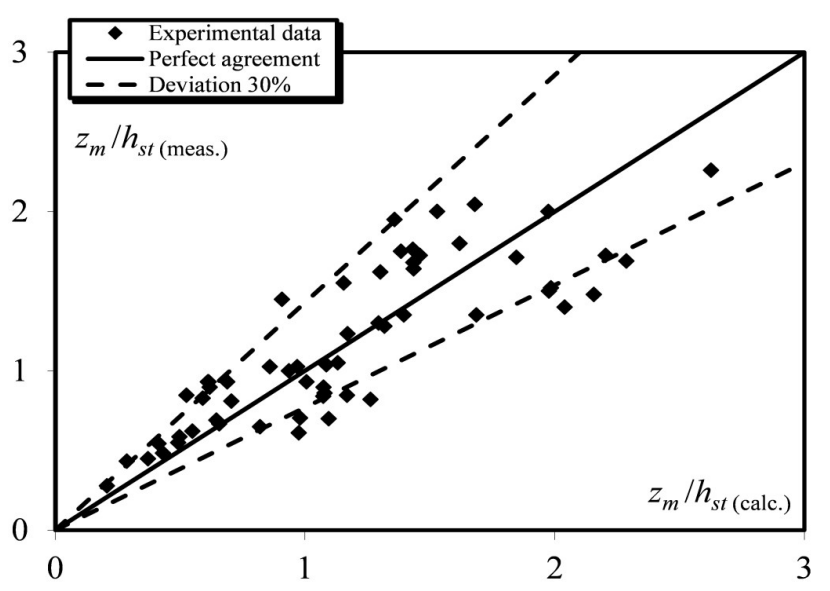

Figure 9 Comparison of calculated (using Eq. 6) and measured values of $z_{m} / h_{s t}$.
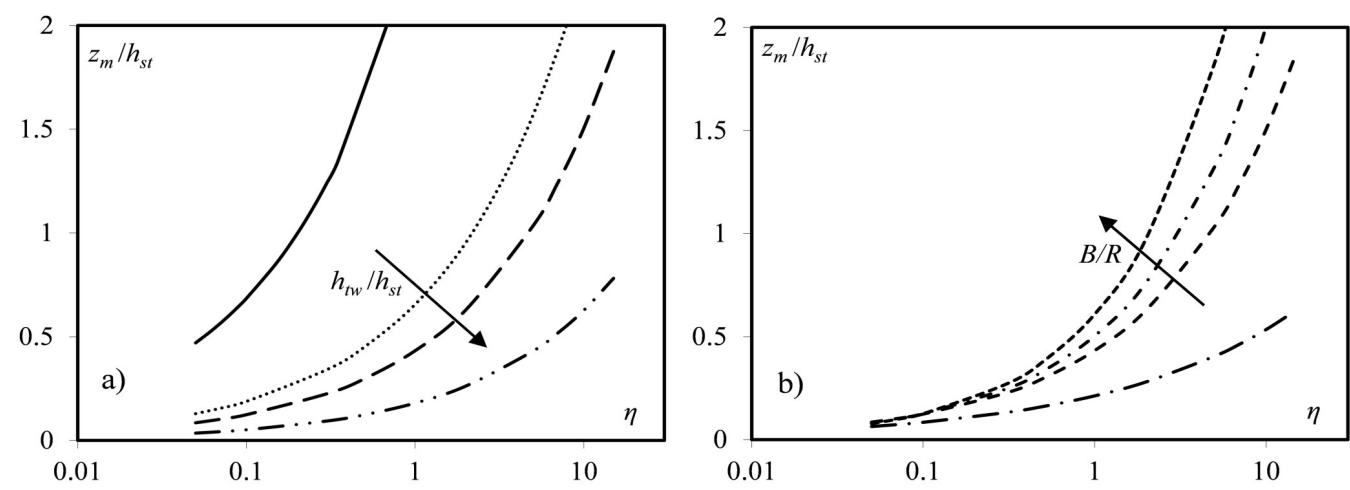

Figure 10 a) Plot of Eq. (6) in curved channel $R=4 \mathrm{~m}$, for $h_{t w} / h_{s t}=1.0[\square], h_{t w} / h_{s t}=$ $2.0[\cdots \cdots \cdots], h_{t w} / h_{s t}=3.0[---], h_{t w} / h_{s t}=4.0[-\cdot-\cdot \cdot-]$, b) Plot of Eq. (6) for different values of $R$ and for $h_{t w} / h_{s t}=2.5: B / R=0.5[-------], B / R=0.25[-\cdot-\cdot-], B / R=0.125[---$ - -], straight channel [-.-.--- ].

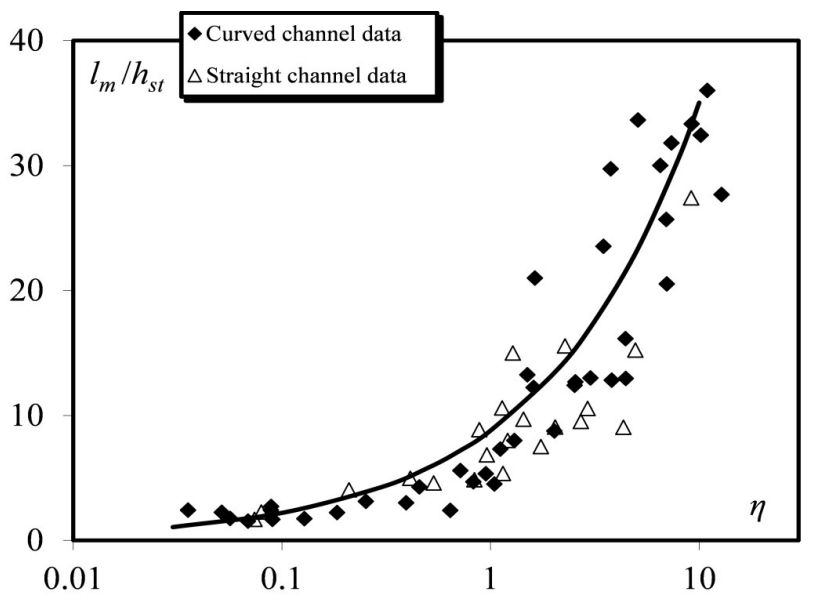

Figure 11 comparison of experimental data with Eq. (8). 


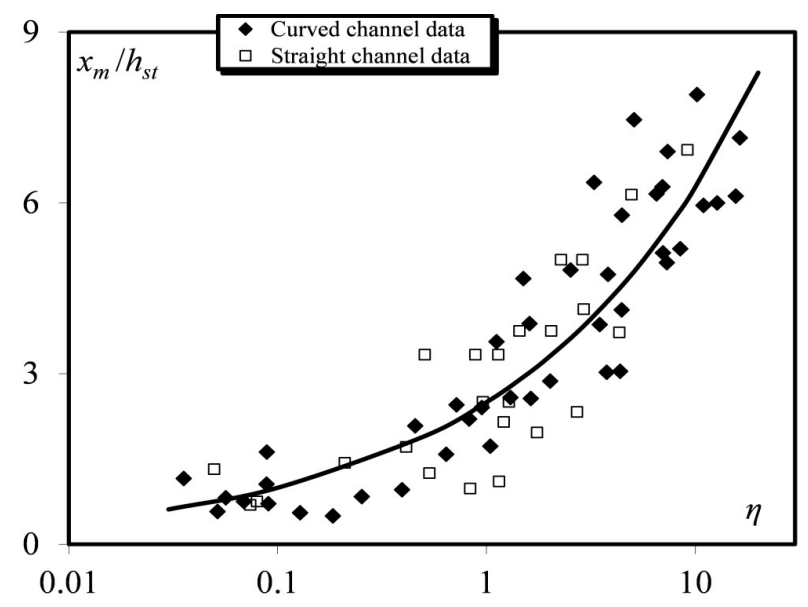

Figure 12 Comparison of experimental data with Eq. (9).

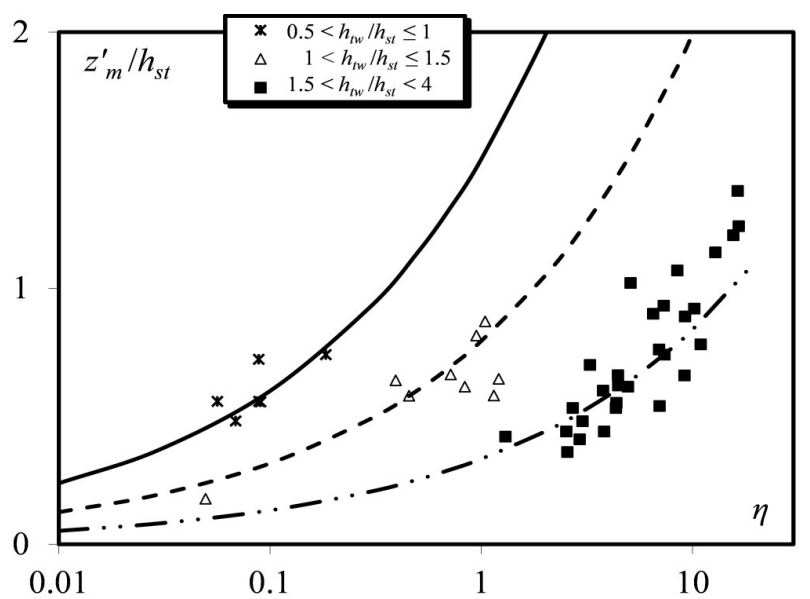

Figure 13 Comparison of Eq. (10) for $h_{t w} / h_{s t}=0.75[\square], h_{t w} / h_{s t}=1.25\left[---_{-}\right]$and $h_{t w} / h_{s t}$ $=2.5[-\cdot \cdot-\cdot \cdot-]$ with observed data.

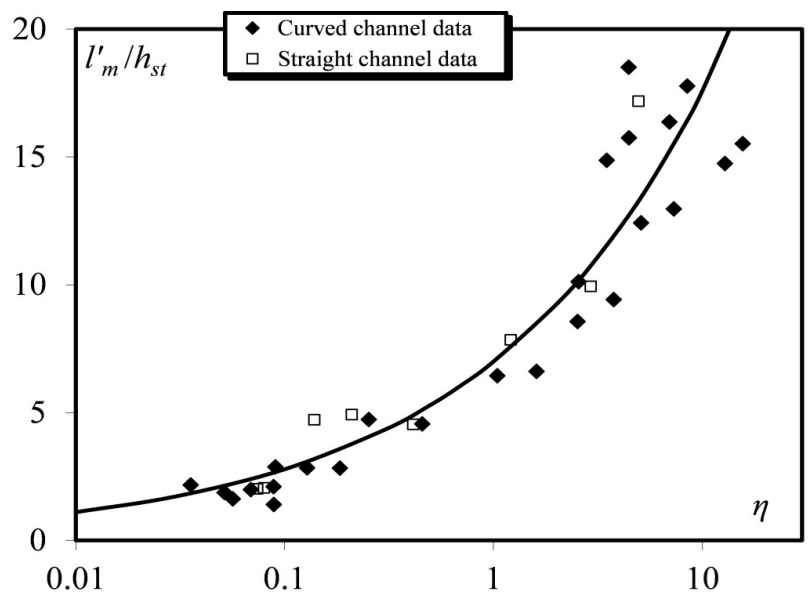

Figure 14 Comparison of Eq. (11) with observed data. 